\title{
Research on Assessment of Cold Drink Brand Competitiveness in Perspective of Consumers
}

\author{
Tao Meng \\ Department of Economics and Management \\ Huai'an Normal University,HNU \\ Huai'an, China \\ mtmxb@163.com
}

\author{
Yancai Zhang, Fengbiao He \\ Department of Economics and Management \\ Huai'an Normal University,HNU \\ Huai'an, China \\ zyancai@163.com
}

\begin{abstract}
The article discussed the competitiveness of brand in cold drink industry by the construction of brand competitiveness assessment index system. In the perspective of consumers, from three dimensions such as brand awareness, brand reputation, and brand loyalty, eighteen items were designed. After the reliability and validity test of data, 17 items were kept in the questionnaire. The distance between consumers' expectation and perception was calculated, the results indicated that the consumers thought highly of the brand reputation. Therefore, the cold drink enterprises should focus on improving and maintaining brand awareness and brand loyalty in order to enhance the brand competitiveness.
\end{abstract}

Keywords-cold drinks industry; brand competitiveness; consumer survey

\section{INTRODUCTION}

In China, the cold drink industry has experienced nearly 20 years of development. Today, because of consumers' mature consumption concept and attitudes, cold drinks are increasingly consumed as snack foods. Due to the great potentials, Chinese cold drink market has attracted many foreign companies. It means the competition in Chinese cold drink market would upgrade and the brands of cold drinks would be completely terminal. Therefore, to enhance the core competitiveness of domestic cold drink brands becomes more crucial. To make objective and scientific assessment of cold drink brand competitiveness will not only help to understand the market conditions, but also provide extremely important reference values for enterprises observing the effectiveness of brand building and rationally distributing resources. By far most assessments are based on internal enterprises to estimate the brand competitiveness, ignoring the evaluations of consumers to some extent. This article starts from consumers and tries to provide references for enterprises applying brand competitiveness improvement strategies by acquiring data and analyzing results.

\section{RESEARCH DESIGN}

People have recognized the brand competitiveness for a long time. Researchers proposed a variety of analytical methods from a different point of view. Different analytical methods are based on various assessment indexes. At present, the assessment indexes of cold drink brand competitiveness mainly concern the market performance of brand, the basic capability of brand, and the comprehensive capability of brand. However, these indexes are more complicated and not operational. Reasons are: (1) the market performance assessment of brand competitiveness is not capable of making in-depth assessment; (2) the basic capability assessment of brand is completely based on internal enterprise, disconnecting practical conditions, and not operational; (3) the comprehensive capability assessment of brand disconnects the consumers to assess and analyze the brand competitiveness. In this article, the author agrees that the brand competitiveness depends on consumers' psychological recognition. Only when consumers recognize the brand advantage, can it turn into brand competitiveness. Therefore, it is a new approach to assess the brand competitiveness by investigating consumers and observing their real reactions to brands.

\section{A. Construction of Brand Competitiveness Assessment Index System}

The strength of brand competitiveness cannot be observed directly. It can be assessed by comprehensive analysis through a few measurable variables. Based on the scientific, systematic, and operational principle, this article starts form consumers' reactions to brands to explore the competitiveness of brands from three dimensions, i.e. the dimension of brand awareness, the dimension of brand reputation, and the dimension of brand loyalty. For each dimension, the article designs six items in the questionnaire. Details are listed in Table I as follow.

\section{B. Data Collection of Questionnaire}

In this research, we collect necessary data by questionnaire. We spent two weeks in sending out 120 questionnaires in the cold drink shops in Nanjing, Changzhou, and Huai' an, and recollected 115 questionnaires. The recovery rate was $95.83 \%$. Excluding 5 invalid questionnaires, we got 110 valid questionnaires. The recovery rate of valid questionnaires was $91.67 \%$. The data was suitable for further analysis. In the design of questionnaire, we take the average of several items evaluating one dimension as the statistic index, in order to improve the stability of parameters in the model. In the consumers' behavior survey, the quality measurement is scored by five levels, i.e. 5 for the most satisfied, 1 for the complete unsatisfied, 2, 3, and 4 respectively for different 
level of satisfaction. This survey tries to be close to target consumers as much as possible. Therefore, consumers' opinions and attitudes have high reference values for the assessment of cold drink brand competitiveness.

TABLE I. THE INDEXES FOR CONSUMER-BASED BRAND COMPETITIVENESS OF COLD DRINK

\begin{tabular}{|c|c|c|}
\hline Dimension & Number & Item \\
\hline \multirow{6}{*}{$\begin{array}{c}\text { Brand } \\
\text { awareness }\end{array}$} & $\chi_{1}$ & Attractiveness of package \\
\hline & $\chi_{2}$ & Brand's commitment to good quality \\
\hline & $\chi_{3}$ & $\begin{array}{l}\text { Good innovation and development in } \\
\text { quality }\end{array}$ \\
\hline & $\chi_{4}$ & $\begin{array}{l}\text { Good brand awareness of different } \\
\text { consumers }\end{array}$ \\
\hline & $\chi_{5}$ & $\begin{array}{l}\text { Wide resources for consumers acquiring } \\
\text { brand information }\end{array}$ \\
\hline & $\chi_{6}$ & $\begin{array}{llll}\begin{array}{l}\text { Conditions for competitive } \\
\text { awareness }\end{array} & & \\
\end{array}$ \\
\hline \multirow{6}{*}{$\begin{array}{l}\text { Brand } \\
\text { reputation }\end{array}$} & $\chi_{7}$ & $\begin{array}{l}\text { High evaluation for the quality of brand } \\
\text { products }\end{array}$ \\
\hline & $\chi_{8}$ & Reasonable prices for brand products \\
\hline & $\chi_{9}$ & Good effects for using the brand \\
\hline & $\chi_{10}$ & Excellent services of the brand \\
\hline & $\chi_{11}$ & Good public image of the brand \\
\hline & $\chi_{12}$ & Sufficient sale channels of the brand \\
\hline \multirow{6}{*}{$\begin{array}{l}\text { Brand } \\
\text { loyalty }\end{array}$} & $\chi_{13}$ & Consumers' preference for the brand \\
\hline & $\chi_{14}$ & Brand extension can also attract consumers \\
\hline & $\chi_{15}$ & Consumers trust the brand \\
\hline & $\chi_{16}$ & $\begin{array}{l}\text { Consumers' high expectations for the } \\
\text { brand }\end{array}$ \\
\hline & $\chi_{17}$ & $\begin{array}{l}\text { Consumers prefer to choose the brand } \\
\text { rather than try others }\end{array}$ \\
\hline & $\chi_{18}$ & $\begin{array}{l}\text { Consumers would like to recommend the } \\
\text { brand to friends }\end{array}$ \\
\hline
\end{tabular}

\section{Evaluation of Data Quality}

Use the software Visual Pls to make reliability test and validity test of variables. The reliability refers to the stability and the dependability of questionnaire result as we use the same approach to investigate same objects. This article mainly adopts the Cronbach's $\alpha$ coefficient method to measure the reliability. Generally, if $\alpha$ is greater than 0.9 , it means high reliability of the scale; if between 0.8 and 0.9 , acceptable; if between 0.7 and 0.8 , questionable but with reference values; if less than 0.7 , questionable and needs to be re-designed.

The validity refers to whether certain measurement tool or method can measure the objects accurately. This article mainly adopts the convergent validity for evaluation. Generally, it is based on the Composite Reliability (CR) and the Average Variance Extracted (AVE). Here, $\mathrm{CR}$ is calculated by the standardized factor loading coefficient of each dimension. As AVE is greater than 0.5 and $\mathrm{CR}$ is greater than 0.7 , the result is more ideal.

\section{Item Adjustment}

After the reliability test and the validity test of each item in the original model, we should adjust the initial items: delete the item $\chi_{17}$ because its standardized factor loading coefficient is less than 0.5 . So, the loading coefficient of each variable in the final model is greater than 0.5 . T-test is greater than 2. The results are listed in Table II. Then, respectively test the reliability and validity of three dimensions and results are displayed in Table III. We can see that $\mathrm{CR}$ is greater than 0.7, AVE is above 0.5, and the validity is relatively ideal; $\alpha$ is between 0.8 and 0.9 , and the reliability is acceptable. It means the design of all items in the questionnaire has certain reference values.

TABLE II. THE LOADING COEFFICIENT AND T-TEST VALUE

\begin{tabular}{|c|c|c|c|c|c|}
\hline $\begin{array}{l}\text { Dime } \\
\text { nsion }\end{array}$ & Item & $\begin{array}{c}\text { Entire } \\
\text { Sample } \\
\text { estimate }\end{array}$ & $\begin{array}{c}\text { Meanof } \\
\text { Subsamples }\end{array}$ & $\begin{array}{l}\text { Standar } \\
\text { d error }\end{array}$ & $\begin{array}{c}\text { T- } \\
\text { Statistic }\end{array}$ \\
\hline \multirow{6}{*}{$\begin{array}{c}\text { Brand } \\
\text { aware } \\
\text { ness }\end{array}$} & $\chi_{1}$ & 0.7610 & 0.7743 & 0.0501 & 15.1878 \\
\hline & $\chi_{2}$ & 0.7187 & 0.7331 & 0.0469 & 15.3612 \\
\hline & $\chi_{3}$ & 0.5941 & 0.5982 & 0.0739 & 8.0405 \\
\hline & $\chi_{4}$ & 0.8057 & 0.8057 & 0.0385 & 20.9666 \\
\hline & $\chi_{5}$ & 0.8098 & 0.8131 & 0.0409 & 19.7728 \\
\hline & $\chi_{6}$ & 0.6986 & 0.7001 & 0.0461 & 15.1438 \\
\hline \multirow{6}{*}{$\begin{array}{l}\text { Brand } \\
\text { reputa } \\
\text { tion }\end{array}$} & $\chi_{7}$ & 0.7736 & 0.7738 & 0.0487 & 15.8823 \\
\hline & $\chi_{8}$ & 0.8060 & 0.8164 & 0.0398 & 20.2507 \\
\hline & $\chi_{9}$ & 0.7709 & 0.7693 & 0.0464 & 16.2602 \\
\hline & $\chi_{10}$ & 0.7468 & 0.7530 & 0.0491 & 15.2312 \\
\hline & $\chi_{11}$ & 0.7175 & 0.7178 & 0.0652 & 11.0063 \\
\hline & $\chi_{12}$ & 0.5473 & 0.5454 & 0.0960 & 5.6998 \\
\hline \multirow{5}{*}{$\begin{array}{l}\text { Brand } \\
\text { loyalty }\end{array}$} & $\chi_{13}$ & 0.8165 & 0.8270 & 0.0355 & 23.0502 \\
\hline & $\chi_{14}$ & 0.8020 & 0.8000 & 0.0557 & 14.3977 \\
\hline & $\chi_{15}$ & 0.7970 & 0.8000 & 0.0392 & 20.3306 \\
\hline & $\chi_{16}$ & 0.8291 & 0.8340 & 0.0406 & 20.4447 \\
\hline & $\chi_{18}$ & 0.8558 & 0.8567 & 0.0271 & 31.6339 \\
\hline
\end{tabular}

TABLE III. THE INDEXES OF RELIABILITY AND VALIDITY

\begin{tabular}{|l|l|l|l|}
\hline \multicolumn{1}{|c|}{ Construct } & $\begin{array}{c}\text { Composite } \\
\text { Reliability }\end{array}$ & AVE & $\begin{array}{c}\text { Cronbach } \\
\text { Alpha }\end{array}$ \\
\hline Brand awareness & 0.874618 & 0.540560 & 0.825497 \\
\hline Brand reputation & 0.870406 & 0.525977 & 0.805618 \\
\hline Brand loyalty & 0.911411 & 0.663637 & 0.856076 \\
\hline
\end{tabular}

\section{RESULTS AND ANALYSES}

Since we have removed the undesirable index $\chi_{17}$ in the reliability test above, we will not make further analysis of this index. Under different weights, score the brand competitiveness: consumers hold different opinions on the relative importance of three dimensions, i.e. some consumers agree that the brand awareness is important, and some think that the brand reputation is important. Therefore, as we score 
the brand competitiveness, we make the relative importance of three dimensions weighted:

$$
B C=\sum_{k=1}^{3} W_{k} \frac{\sum_{i=1}^{n}\left(P_{i}-E_{i}\right)}{n} .
$$

Here, BC represents brand competitiveness; $\mathrm{P}$ represents the consumers' perception of brand competitiveness; $\mathrm{E}$ represents consumers' expectations for certain brand; W represents the weight of each dimension; $n$ represents the number of consumers in each case; $\mathrm{i}=1, \ldots, 110 ; \mathrm{k}=1,2,3 ; \mathrm{E}$ is 5 in this article; use the loading coefficient represent the weight of each item. all the $\mathrm{BC}$ values are negative, i.e. consumers' perception of brand competitiveness does not reach the expectation. The bigger the absolute value of $\mathrm{BC}$, the larger the distance between consumers' expectation for Chinese cold drink's brand competitiveness and the consumers' actual perception is.

\section{A. Analysis of Cold Drink Brand Awareness}

From Table IV and V, we can see: as for the brand awareness of cold drink, the scores of all items are above the average 2.5. Comparatively speaking, for the attractiveness of package and the brand commitment to quality, consumers' perception is higher, respectively reaching 3.48 and 3.47. For the innovation of brand and the brand awareness among different consumers, consumers' perception reaches 3.3. For the resources of consumers acquiring brand information and the perception of competitive brand, the consumers' perception is less than 3, relatively lower. At the same time, for the brand commitment to quality and the brand innovation and development, consumers have the same perception. For other four items, there are relative differences for consumers' perception. From the BC values of the six items of cold drink brand awareness, the distance between consumers' expectation for resources of acquiring brand information and consumers' perception is the largest; secondly, it is the distance between consumers' perception of competitive brand; the distance between consumers' expectation for brand innovation and development and consumers' perception is the smallest.

TABLE IV. BRAND AWARENESS DESCRIPTIVE STATISTICS

\begin{tabular}{|c|c|c|c|c|c|}
\hline Item & $\mathbf{N}$ & Min. & Max. & Mean & $\begin{array}{c}\text { Standard } \\
\text { deviation }\end{array}$ \\
\hline$\chi_{1}$ & 110 & 1 & 5 & 3.48 & 1.311 \\
\hline$\chi_{2}$ & 110 & 1 & 5 & 3.47 & 0.896 \\
\hline$\chi_{3}$ & 110 & 1 & 5 & 3.30 & 0.884 \\
\hline$\chi_{4}$ & 110 & 1 & 5 & 3.30 & 1.162 \\
\hline$\chi_{5}$ & 110 & 1 & 5 & 2.97 & 1.153 \\
\hline$\chi_{6}$ & 110 & 1 & 5 & 2.90 & 1.219 \\
\hline
\end{tabular}

TABLE V. EXPECTED AND PERCEPTIOM VALUE OF BRAND AWARENESS

\begin{tabular}{|c|c|c|c|c|c|c|}
\hline $\begin{array}{c}\text { Dimen- } \\
\text { sion }\end{array}$ & Item & $\begin{array}{c}\text { Expec } \\
\text {-tion }\end{array}$ & $\begin{array}{c}\text { Percep } \\
\text { tiom }\end{array}$ & Weight & $\begin{array}{c}\text { weighted } \\
\text { values } \\
(\mathrm{BC})\end{array}$ & $\begin{array}{l}\text { Mean } \\
\text { of BC }\end{array}$ \\
\hline \multirow{7}{*}{$\begin{array}{c}\text { Bran } \\
\mathrm{d} \\
\text { awar } \\
\text { enes } \\
\mathrm{s}\end{array}$} & $\chi_{1}$ & 5 & 3.48 & 0.7610 & -1.15672 & \multirow{7}{*}{1.29116} \\
\hline & $\chi_{2}$ & 5 & 3.47 & 0.7187 & -1.09961 & \\
\hline & & & & & & \\
\hline & $\chi_{3}$ & 5 & 3.30 & 0.5941 & -1.00997 & \\
\hline & $\chi_{4}$ & 5 & 3.30 & 0.8057 & -1.36969 & \\
\hline & $\chi_{5}$ & 5 & 2.97 & 0.8098 & -1.64389 & \\
\hline & $\chi_{6}$ & 5 & 2.90 & 0.6986 & -1.46706 & \\
\hline
\end{tabular}

\section{B. Analysis of Cold Drink Brand Reputation}

From TableVI and VII, we can see that: consumers hold similar perception of cold drink brand reputation. The brand reputation is relatively better. Consumers agree that brand products have better services close to the expectation. Only for the sale channel of brand cold drinks, consumers have different opinions. However, it still relatively meets consumers' expectation.

TABLE VI. BRAND REPUTATION DESCRIPTIVE STATISTICS

\begin{tabular}{|c|c|c|c|c|c|}
\hline Item & $\mathbf{N}$ & Min. & Max. & Mean & $\begin{array}{c}\text { Standard } \\
\text { deviation }\end{array}$ \\
\hline$\chi_{7}$ & 110 & 2 & 5 & 3.40 & 0.693 \\
\hline$\chi_{8}$ & 110 & 2 & 5 & 3.55 & 0.659 \\
\hline$\chi_{9}$ & 110 & 2 & 5 & 3.40 & 0.652 \\
\hline$\chi_{10}$ & 110 & 2 & 5 & 3.62 & 0.742 \\
\hline$\chi_{11}$ & 110 & 2 & 5 & 3.38 & 0.635 \\
\hline$\chi_{12}$ & 110 & 1 & 5 & 3.30 & 0.963 \\
\hline
\end{tabular}

TABLE VII. EXPECTED AND PERCEPTIOM VALUE OF BRAND REPUTATION

\begin{tabular}{|c|c|c|c|c|c|c|}
\hline $\begin{array}{l}\text { Dimen- } \\
\text { sion }\end{array}$ & Item & $\begin{array}{c}\text { Expec } \\
\text { tion }\end{array}$ & $\begin{array}{c}\text { Percep } \\
\text {-tiom }\end{array}$ & Weight & $\begin{array}{c}\text { weighted } \\
\text { values } \\
\text { (BC) }\end{array}$ & $\begin{array}{l}\text { Mean } \\
\text { of BC }\end{array}$ \\
\hline \multirow{6}{*}{$\begin{array}{c}\text { Brand } \\
\text { reputati } \\
\quad 0\end{array}$} & $\chi_{7}$ & 5 & 3.40 & 0.7736 & -1.23776 & \multirow{6}{*}{$\begin{array}{c}- \\
1.1665 \\
7\end{array}$} \\
\hline & $\chi_{8}$ & 5 & 3.55 & 0.8060 & -1.1687 & \\
\hline & $\chi_{9}$ & 5 & 3.40 & 0.7709 & -1.23344 & \\
\hline & $\chi_{10}$ & 5 & 3.62 & 0.7468 & -1.03058 & \\
\hline & $\chi_{11}$ & 5 & 3.38 & 0.7175 & -1.16235 & \\
\hline & $\chi_{12}$ & 5 & 3.30 & 0.5473 & -0.93041 & \\
\hline
\end{tabular}

\section{Analysis of Cold Drink Brand Loyalty}

Table VIII and IX show that: the average of all items of brand loyalty is all above 3, higher than the middle level. For the brand extension and the trust in brand, consumers develop similar ideas. The distance between brand awareness and expectation is small. If consumers have certain preference to one brand, the distance between perception and expectation is the largest. The cold drink brand needs to adopt new methods to improve consumers' interests in the 
brand, retain existing customers, and improve the customer loyalty.

TABLE VIII. BRAND REPUTATION DESCRIPTIVE STATISTICS

\begin{tabular}{|l|l|l|l|l|l|}
\hline Item & $\mathbf{N}$ & Min. & Max. & Mean & $\begin{array}{c}\text { Standard } \\
\text { deviation }\end{array}$ \\
$\chi_{13}$ & 110 & 1 & 5 & 3.10 & 1.133 \\
$\chi_{14}$ & 110 & 1 & 5 & 3.38 & 0.995 \\
$\chi_{15}$ & 110 & 1 & 5 & 3.51 & 0.843 \\
$\chi_{16}$ & 110 & 1 & 5 & 3.27 & 1.108 \\
$\chi_{18}$ & 110 & 1 & 5 & 3.40 & 1.228 \\
\hline
\end{tabular}

TABLE IX. EXPECTED AND PERCEPTIOM VALUE OF BRAND LOYALTY

\begin{tabular}{|c|c|c|c|c|c|c|}
\hline $\begin{array}{c}\text { Dime } \\
\text { n-sion }\end{array}$ & Item & $\begin{array}{c}\text { Expec- } \\
\text { tion }\end{array}$ & $\begin{array}{c}\text { Percep } \\
- \\
\text { tiom } \\
\end{array}$ & Weight & $\begin{array}{c}\text { weighted } \\
\text { values } \\
(\text { BC })\end{array}$ & $\begin{array}{l}\text { Mean } \\
\text { of } B C\end{array}$ \\
\hline \multirow{5}{*}{$\begin{array}{l}\text { Bran } \\
\text { d } \\
\text { loyal } \\
\text { ty }\end{array}$} & $\chi_{13}$ & 5 & 3.10 & 0.8165 & -1.55135 & \multirow{5}{*}{$\begin{array}{c}- \\
1.3683 \\
5\end{array}$} \\
\hline & $\chi_{14}$ & 5 & 3.38 & 0.8020 & -1.29924 & \\
\hline & $\chi_{15}$ & 5 & 3.51 & 0.7970 & -1.18753 & \\
\hline & $\chi_{16}$ & 5 & 3.27 & 0.8291 & -1.43434 & \\
\hline & $\chi_{18}$ & 5 & 3.40 & 0.8558 & -1.36928 & \\
\hline
\end{tabular}

\section{CONCLUSION}

By comparing the brand awareness, brand reputation, and brand loyalty of Chinese cold drink brands, we can notice that the distance between consumers' expectation and perception could be listed from the smallest to the largest as: brand reputation, brand awareness, brand loyalty. For cold drink brands, the brand reputation is the best among consumers' perception. Based on optimizing the sale channels, we should focus on improve and maintain brand awareness and brand loyalty. First of all, by focusing on brand marketing terminals, we can stress on the expansion channels of cold drink brand, and create a good atmosphere of brand awareness. Secondly, strengthen the brand commitment and keep consumers. Thirdly, cold drink enterprises should develop brand marketing services and enhance the awareness of terminal services. Finally, implement the niche marketing strategy, improve consumers' brand expectation, and further achieve the expected growth of brand consumption by following customers' consuming psychology and behaviors.

\section{ACKNOWLEDGMENT}

2011 Young Talents Support Project from HNU (11HSQNS19)

\section{REFERENCES}

[1] F. Zhao, Z. Q. Zou, "evaluation mode Design and Experimental Research on the cigarette brand competitiveness," Guangxi Social Sciences, pp. 52-55, Sept 2010.

[2] X. M. Ni, Proficient in SPSS statistical analysis, Tsinghua University press, 2010.

[3] O. Hirschman, Exit, Voice, and Loyalty: Responses to Decline in Firms, Organizations, and States. Cambridge, MA:Harvard University Press, 170.

[4] M. Y. Yu, S. S. Yang, Brand marketing management, Wuhan:Wuhan University press, 2008. 